\title{
Evaluation of carbon stocks in the soils of Lena River Delta on the basis of application of "dry combustion" and Tyurin's methods of carbon determination
}

\author{
Vyacheslav Polyakov ${ }^{1}, K^{\prime}$ senia Orlova', and Evgeny Abakumov ${ }^{1}$ \\ ${ }^{1}$ Department of Applied Ecology, Faculty of Biology, St. Petersburg State University, \\ 16 ${ }^{\text {th }}$ Liniya V. O., 29, St. Petersburg, 199178, Russian Federation; slavon6985@gmail.com \\ Address correspondence and requests for materials to Vyacheslav Polyakov
}

\begin{abstract}
The aim of this paper is evaluation of carbon stocks in the soils of the Lena River Delta by two methods: "dry combustion" and Tyurin's methods, as well as their comparison. This work presents methodical aspect and data on the estimation of organic carbon stocks in the soils of the Lena River Delta. Here we show that the data on the content of organic carbon based on dichromate oxidation by Tyurin's method differed significantly from the actual carbon content of organic substances, derived from application of "dry combustion" method based on direct accounting of emitted $\mathrm{CO}_{2}$ from soils it uses of chromatography techniques. Due to this difference, the application of Tyurin's method can lead to incorrect estimate of carbon stocks in the soil. This knowledge is very important for correct estimation of soil ecological functions related to stabilization of organic matter.
\end{abstract}

Keywords: Total organic carbon, Arctic zone, carbon storage, Lena River Delta, carbon determination

Citation: Polyakov, V., Orlova, K., and Abakumov, E. 2017. Evaluation of carbon stocks in the soils of Lena River Delta on the basis of application of "dry combustion" and Tyurin's methods of carbon determination. Bio. Comm. 62(2): 67-72. doi: 10.21638/11701/spbu03.2017.202

Author's information: Polyakov Vyacheslav, student, orcid.org/0000-00016171-3221, Researcher ID: H-5483-2016, Orlova Ksenia, student, orcid.org/00000003-3063-0604, Researcher ID: J-51302017, Abakumov Evgeny, Dr. Sci., Professor, orcid.org/0000-0002-5248-9018, Researcher ID: B-5291-2013

Manuscript Editor: Prof. Cezary Kabala, Institute of Soil Science and Environmental Protection, Wroclaw University of Environmental and Life Sciences, Wroclaw, Poland

Received: June 11, 2017;

Revised: August 16, 2017;

Accepted: August 16, 2017;

Copyright: @ 2017 Polyakov et al. This is an open-access article distributed under the terms of the License Agreement with Saint Petersburg State University, which permits to the authors an unrestricted distribution and self-archiving free of charge.

Funding: This work was supported by the Russian Foundation of the Basic Research (project No 16-34-60010).

Competing interests: The authors have declared that no competing interests exist.

\section{Introduction}

Cryolithozone soil covers more than $8.6 \mathrm{~km}^{2}$, that is about $27 \%$ of all the land areas located up to $50^{\circ} \mathrm{N}$, and accumulates a great amount of organic carbon. In this regard, cryolithozone soils are considered to be one of the most important cryosphere elements. To date, there have been accumulated more than 1024 petagrams (1 petagram $=1 * 10^{13} \mathrm{~kg}$ ) of organic soil carbon in a layer up to $3 \mathrm{~m}$ (Zubrzycki et al., 2013; Zubrzycki et al., 2014).

One of the main reservoirs of organic carbon within the Earth's biosphere presented by soils, especially Arctic soils that contain large amounts of organic matter. Accumulation of organic matter in permafrost soils during thousands of years is a result of low temperatures and high moisture conditions that are typical for Arctic ecosystems (Ejarque and Abakumov, 2016; Cauwet and Sidorov, 1996; Höfle et al., 2013). An analysis data of permafrost-underlain arctic areas - permafrost-affected soils is important for refining current assessments of soil carbon stocks. Moreover, Arctic soil matter remained a vulnerable carbon pool that due to increasing temperatures is susceptible to remobilization (Ejarque and Abakumov 2016; Knoblauch et al., 2013; Lara et al., 1998).

Several methods are available to estimate soil carbon. Here we present data obtained by using "dry combustion" and Tyurin's methods. The "dry combustion" method consists in determination of organic carbon through measuring amount of carbon dioxide released by dry combustion (active carbon pools). The proposed method has precedence over the other modern methods. Tyurin's method provides a wide range of tasks a part from determination of soil carbon, for example, measures carbon dioxide for determination of isotopic composition of 
different forms of carbon, assessment the extent of soil contamination by carbonaceous pollutants, etc (Betelev, 2006). Worldwide, researchers commonly use also Walkley-Black method. This method is based on principle of carbon oxidation by $\mathrm{K}_{2} \mathrm{Cr}_{2} \mathrm{O}_{7}$ and concentrated $\mathrm{H}_{2} \mathrm{SO}_{4}$ solution, after cooling a sample; here $\mathrm{H}_{3} \mathrm{PO}_{4}$ solution is added to the sample in order to negate the accuracy that can appear due to $\mathrm{Fe}^{+3}$ presence. However, this procedure does not lead to complete carbon oxidation. Oxidation rate varies from 60 to $86 \%$, annual rate is about $76 \%$. In that regard, correction factor was introduced (with a value 1.33 in calculating) to negate a mistake of carbon estimation. Using Tyurin's method (total carbon pools), the resulting mixture is boiled and then titrated with Mohl's salt, which is more effective than the Walkley-Black method and does not require a corrective factor (Schumacher, 2002). Determination of the humus carbon by Tyurin's method is frequently become inaccurate. The accuracy rises from specificity and peculiarity of Tyurin's method and determination of organic carbon by the oxidizability. Decrease of the humus oxidizability determines decrease of the carbon determination results (Schumacher, 2002; Bezuglova et al., 2014). When determining the carbon content by the Tyurin's method, an error arises due to the oxidation of humus. If the oxidation of the humus determined by the structure of the molecules of humic acids for some reason decreases, then the result of determining humus is too low. In addition to the degree of oxidation of humus, the obtained value can be affected by halogens and $\mathrm{Fe}^{+2}$ in the soil, which also consumes potassium dichromate (Bezuglova et al., 2014; Abakumov and Popov, 2005).

There is a clear need to use correction factors for calculating soil carbon by Tyurin's method. Studies devoted to this topic were performed by Kogut and his colleagues by automatic analyzers. Some researches proposed a conversion rate to estimate carbon data from Tyurin's method to "dry combustion" methods that takes into account features of intramolecular oxidation of organic matter (Kogut et al., 1992; Kogut and Frid, 1993).

\section{Materials and methods}

\section{STUDY SITES}

Soils of the Lena River Delta were chosen for estimation of accuracy of methods of carbon determination as soils with very high content and stocks of carbon. The Lena Delta is one of the greatest deltas in the world and the greatest Russian river delta that is located in the Arctic zone. Within joint Russian-German projects, expeditions were undertaken in August 2015 and August 2016 to the Lena Delta, Russian Arctic. Field work was conducted in central and western parts of the delta (Figs 1,2).

The Lena Delta is one of the greatest deltas in the zone of continuous permafrost and covers about
$28,000 \mathrm{~km}^{2}$. The territory is characterized by a network of rivers and channels of small and large sizes, and more than 1000 islands. The climate is arctic continental and it is characterized by low air temperatures, low precipitation (however, moisture conditions are high) and low vegetation period. The mean annual temperature is $-10.2^{\circ}-(-13)^{\circ} \mathrm{C}$, the mean annual amounts of precipitation 140-190 mm (Bolshiyanov et al., 2013). The topography of the delta is almost flat. Thickness of permafrost in this area is about $500-600 \mathrm{~m}$ (Schneider et al., 2009). The delta consists of the modern floodplains levels and up to three terraces (the first, the second, and the third), which contrast by their surface (Schneider et al., 2008; Zubrzycki et al., 2013). The territory covered by tundra vegetation of different types.

Soil cover of the delta is characterized by a great spatial diversity and dynamism. Soils of the Lena River Delta as diagnosed according to "World reference base for soil resources..." (WRB, 2014). The six main soil types are identified. $\mathrm{Fe} / \mathrm{Al}$ chemism determines Podzols soil group. Cryosols form on continuous permafrost, soil formation increasingly linked to permafrost-affected horizon Cryic, where permafrost processes determine soil formation. Fluvisols - horizon's differentiation is low or absent. River sedimentation prevailed. Umbrisols are characterised by organic matter accumulation in the upper layer with a small thickness. Histosols - soils group with a massive organic horizon that involve processes of peat formation and peat accumulation. Gleysols include peat horizon with underlay gley horizon. The Lena River Delta soils were formed in different time and under various factors. Podzols were formed in wet tundra, Cryosols - in dry tundra. Fluvisols are related with flood plain vegetation and ongoing redeposition of matter. Umbrisols soils type's distinctive feature is primal processes of soil formation and matter accumulation. Histosols are typical zonal group of soils that form in lowlands, also they are the oldest soils type in the river delta. Gleysols are located in lowlands in over-wetted conditions.

\section{SAMPLING STRATEGY}

Samples of soil were selected in various elements of the landscape. Several profiles were made in the areas subject to annual flooding and the places of the alreadyreleased conditions. The depth of the incisions reached $80 \mathrm{~cm}$ for Fluvisols and up to 50 for the other soil types. Soil construction was laid in various elements of the landscape. They were micro depressions, hills, flooded areas, slopes of terraces.

\section{LABORATORY METHODS}

To evaluate the volumetric content of carbon in the fine earth we had used data of "dry combustion" $\left(\mathrm{CCO}_{2}\right)$ and Tyurin's (Cox) methods. The determination of $\mathrm{CCO}_{2}$ is based 

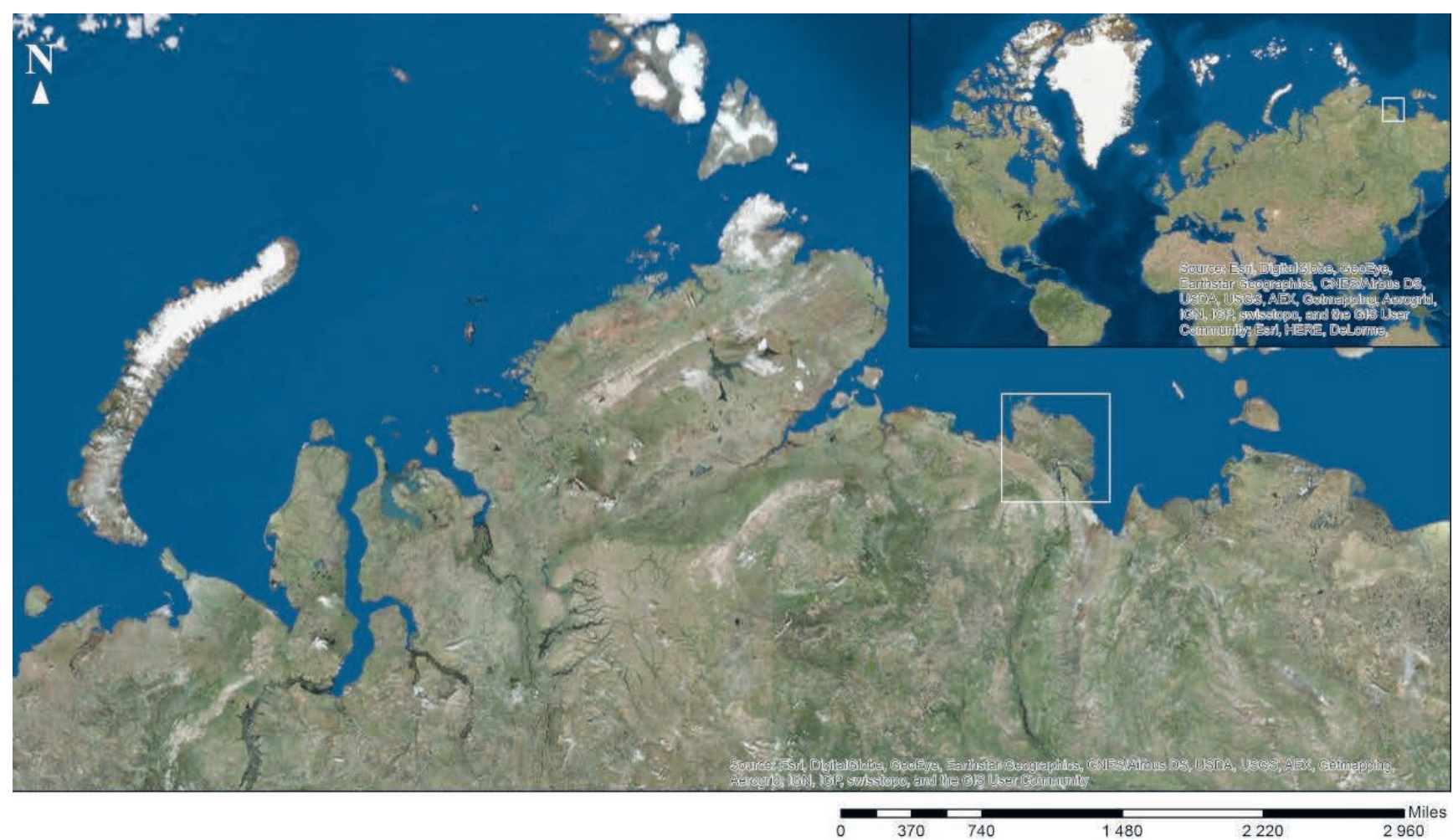

2220

Fig. 1. The key investigation sites of the Lena River Delta, Russian Arctic

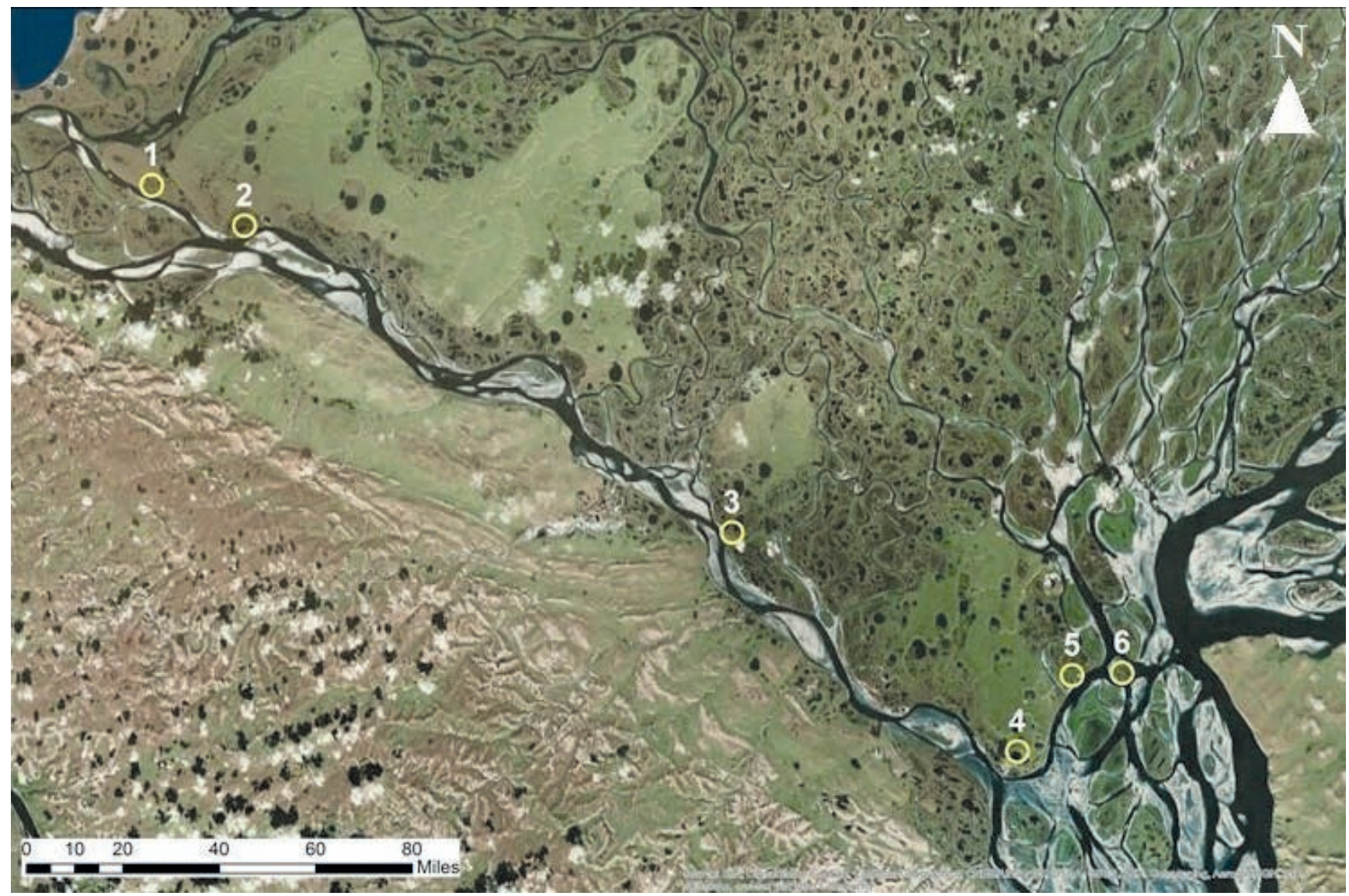

Fig. 2. Study sites of the Lena River Delta, Russian Arctic. Distribution of soils within the study area: 1) isl. Hardang (Histosols); 2) isl. Hardang (Umbrisols); 3) isl. Jan-Gylach (Podzols); 4) isl. Kurungnagh (Cryosols); 5) isl. Kurungnagh (Gleysols); 6) isl. Samoylov (Fluvisols). 


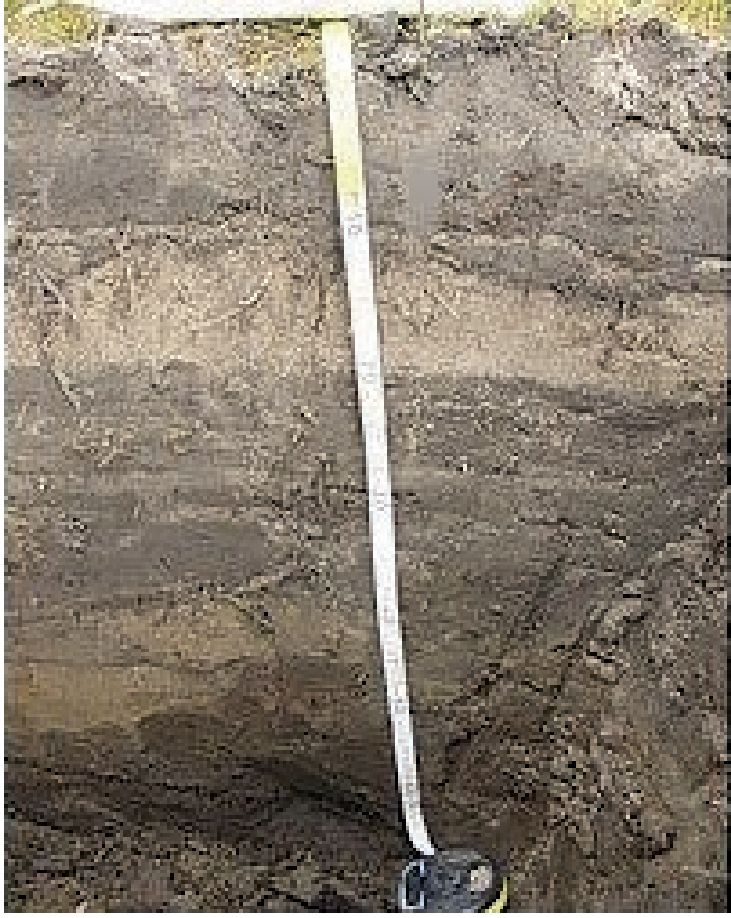

A

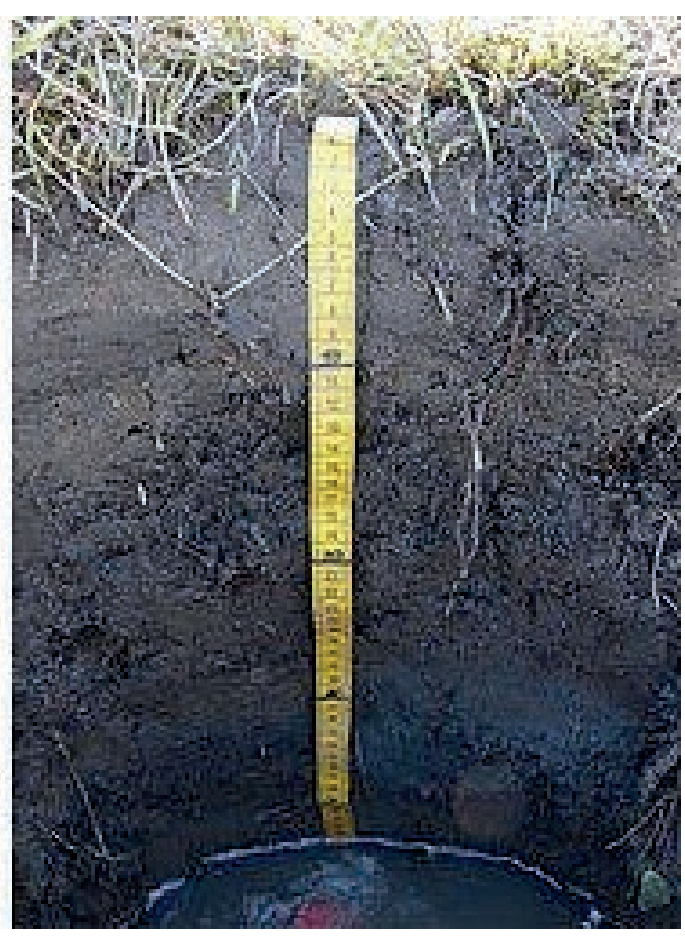

B

Fig. 3. Morphological diversity of soil in Lena River Delta: A - Fluvisols (Arenic), B - Folic Cryosols (Fluvic)

on sample direct combustion and further evaluation of emitted $\mathrm{CO}_{2}$ by chromatography. During oxidation all the organic carbon turns into carbon dioxide. Further on, in resulting products of combustion utilized from chlorides and other halogens, the measurement of carbon dioxide takes place (Abakumov and Popov, 2005). To refine Cox we used Tyurin's method (Orlov, 1985). The main principle of Tyurin's method is wet combustion of sample by $\mathrm{K}_{2} \mathrm{Cr}_{2} \mathrm{O}_{7}$ solution in sulphuric acid followed by determination of oxidizer value by titration method using Mohr's salt. All measurements were performed in triplicate.

\section{Results and discussion}

In this work volumetric content of organic carbon in soil was estimated using "dry combustion" method. We then compared the results obtained by "dry combustion" and Tyurin's (Orlov, 1985) methods (Table 1). Fluvisols are characterised by well-stratificated soil profile by $\mathrm{CCO}_{2}$ and Cox values. The degree of reduction-oxidation of organic matter requires special attention. Negative degree demonstrates oxidation processes in soil: in upper layers sea salts tend to accumulate during impulverization; lower layers, where gleying processes occur, have positive $\mathrm{d}$ values. Uprated negative values indicate overestimated carbon value due to presence of halogens or high content hydrogen in molecules that take extra forces of oxidizer $\left(\mathrm{K}_{2} \mathrm{Cr}_{2} \mathrm{O}_{7}\right)$. Greater part of horizons susceptible to oxidation processes of organic matter due to dynamic humus accumulation. Lower layers and layers underlaid by continuous permafrost, red-ox value is tending toward zero or has positive rates, reflecting reduction processes. This trend can be seen within Fluvisols, Cryosols, and Gleysols groups of soils. Only the Cryosols within humus accumulating horizon has positive red-ox value that indicates intensive cryogenesis, particularly cryogenic sorting and patterned ground. Determining the carbon content by direct combustion (active Carbon pools) is determined, and using the Tyurin's method, the total carbon pools, which includes the carbon of partially decomposed and nondecomposed plants, animals, fungi, and bacteria in soil. Therefore, when comparing these two methods, a difference in values in magnitude of 2-3 times can arise.

Table 2 presents the ratio of carbon to nitrogen. That rate indicates the humus enriched with nitrogen. Greater part of soils relates to very low $(>14)$ and low (11-14) degrees of nitrogen enrichment (Orlov, 1985). Young soils of the Lena River Delta that are less affected by the zonal type of processes of soil formation (Fluvisols, Umbrisols, Podzols) have higher degree of nitrogen enrichment due to more enriched with nitrogen crop residues. Soils that are characterized by zonal processes of soil formation (cryogenesis) have very low and low degrees of nitrogen enrichment. Values obtained by Tyurin's method are 3-4 times more than values obtained by "dry combustion" method of carbon determination. The resulting data represents different evaluative information when using different methods. 


\begin{tabular}{|c|c|c|c|c|c|}
\hline $\begin{array}{l}\text { Hori- } \\
\text { zon }\end{array}$ & \begin{tabular}{|c} 
Depth, \\
cm
\end{tabular} & $\mathrm{CCO}_{2}$ & Cox & d, $\%$ & Kc \\
\hline \multicolumn{6}{|c|}{ Fluvisols } \\
\hline AY & $0-7$ & $0.54 \pm 0.003$ & $1.25 \pm 0.01$ & $-132.6 \pm 0.663$ & $0.43 \pm 0.002$ \\
\hline C & $7-12$ & $1.81 \pm 0.009$ & $2.67 \pm 0.021$ & $-47.4 \pm 0.237$ & $0.68 \pm 0.003$ \\
\hline RY & $12-22$ & $0.19 \pm 0.001$ & $0.54 \pm 0.004$ & $-188.7 \pm 0.944$ & $0.35 \pm 0.002$ \\
\hline C & $22-41$ & $1.7 \pm 0.009$ & $2.22 \pm 0.018$ & $-30.8 \pm 0.154$ & $0.76 \pm 0.004$ \\
\hline RY & $41-47$ & $0.17 \pm 0.001$ & $0.08 \pm 0.001$ & $51.6 \pm 0.258$ & $2.07 \pm 0.01$ \\
\hline C & $47-70$ & $2.94 \pm 0.015$ & $3.17 \pm 0.025$ & $-7.7 \pm 0.039$ & $0.93 \pm 0.005$ \\
\hline \multicolumn{6}{|c|}{ Umbrisols } \\
\hline 0 & $0-7$ & $1.6 \pm 0.008$ & $1.54 \pm 0.012$ & $3.6 \pm 0.018$ & $1.04 \pm 0.005$ \\
\hline AY & $7-30$ & $0.93 \pm 0.005$ & $4.14 \pm 0.033$ & $-345 \pm 1.725$ & $0.22 \pm 0.001$ \\
\hline Gox & $30-60$ & $0.33 \pm 0.002$ & $0.64 \pm 0,005$ & $-93.1 \pm 0.466$ & $0.52 \pm 0.003$ \\
\hline \multicolumn{6}{|c|}{ Podzols } \\
\hline AY & $0-15$ & $0.54 \pm 0.003$ & $1.25 \pm 0,01$ & $-132.6 \pm 0.663$ & $0.43 \pm 0.002$ \\
\hline $\mathrm{BHF}$ & $15-28$ & $1.81 \pm 0.009$ & $2.67 \pm 0.021$ & $-47.4 \pm 0.237$ & $0.68 \pm 0.003$ \\
\hline CRg & $28-60$ & $1.4 \pm 0.007$ & $2.6 \pm 0.021$ & $-85.8 \pm 0.429$ & $0.54 \pm 0.003$ \\
\hline \multicolumn{6}{|c|}{ Cryosols } \\
\hline 0 & $0-7$ & $3.22 \pm 0.016$ & $25.09 \pm 0.125$ & $-680.3 \pm 3.402$ & $0.13 \pm 0.001$ \\
\hline AY & $7-16$ & $2.62 \pm 0.013$ & $1.07 \pm 0.009$ & $59.2 \pm 0.296$ & $2.45 \pm 0.012$ \\
\hline CR & $16-27$ & $2.95 \pm 0.015$ & $8.11 \pm 0.065$ & $-174.7 \pm 0.874$ & $0.36 \pm 0.002$ \\
\hline Cox & $27-35$ & $2.24 \pm 0.011$ & $2.82 \pm 0.023$ & $-26 \pm 0.13$ & $0.79 \pm 0.004$ \\
\hline \multicolumn{6}{|c|}{ Histosols } \\
\hline 0 & $0-8$ & $0.9 \pm 0.005$ & $31.5 \pm 0.158$ & not defined & $0.03 \pm 0.0002$ \\
\hline Teg & $8-20$ & $1 \pm 0.005$ & $1.45 \pm 0.012$ & $-45.5 \pm 0.228$ & $0.69 \pm 0.003$ \\
\hline \multicolumn{6}{|c|}{ Gleysols } \\
\hline $\mathrm{O}$ & $0-7$ & $4.96 \pm 0.025$ & $12 \pm 0.06$ & $-142 \pm 0.71$ & $0.41 \pm 0.002$ \\
\hline $\mathrm{AH}$ & $7-20$ & $4.47 \pm 0.022$ & $21 \pm 0.105$ & $-369.6 \pm 1.848$ & $0.21 \pm 0.001$ \\
\hline G & $20-25$ & $2.47 \pm 0.012$ & $1.61 \pm 0.013$ & $35 \pm 0.175$ & $1.54 \pm 0.008$ \\
\hline
\end{tabular}

Table 3 presents the values of carbon stocks in the Lena River Delta. Groups of soils studied by Tyurin's method have overestimate values, $2-3$ times more than values obtained using "dry combustion" method. The more common value of $\mathrm{CcO}_{2}$ and Cox is within Fluvisols, indicating low salt content and low rates of red-ox in this type of soils. Peat horizons are characterized by high oxidation state of organic matter. During the impulverization sea salts accumulates in soil's upper layer. That salt content influences on the resulting values of organic carbon in soils obtained using Tyurin's method. Histosols are characterized by a very large difference between values obtained by the "dry combustion" and Tyurin's methods of determination of organic carbon. This may be due to the fact that this type of soils contains a large amount of organic matters. Histosols mainly consist of mosses of varying degrees of decomposition, so a large amount of potassium dichromate is consumed for oxidation of this type of soil.

Analytical results permit the determination of carbon stocks within each horizon:

$$
\mathrm{SOC}=\rho * \mathrm{Coc} * \mathrm{H} * 0,1,
$$

Table 2. Results of the $\mathrm{C} / \mathrm{N}$ ratio determination for all six investigated soil group in "dry combustion" and Tyurin's method \pm SD

\begin{tabular}{|c|c|c|c|}
\hline Horizon & $\begin{array}{l}\text { Depth, } \\
\text { cm }\end{array}$ & $\begin{array}{l}\mathrm{C} / \mathrm{N} \text { in } \\
\text { "dry combustion" } \\
\text { methods }\end{array}$ & $\begin{array}{c}\mathrm{C} / \mathrm{N} \text { in } \\
\text { Tyurin's method }\end{array}$ \\
\hline \multicolumn{4}{|c|}{ Fluvisols } \\
\hline AY & $0-7$ & $9 \pm 0.045$ & $20 \pm 0.16$ \\
\hline C & $7-12$ & $13 \pm 0.065$ & $19 \pm 0.152$ \\
\hline RY & $12-22$ & $5 \pm 0.025$ & $13 \pm 0.104$ \\
\hline C & $22-41$ & $12 \pm 0.06$ & $16 \pm 0.128$ \\
\hline RY & $41-47$ & $5 \pm 0.025$ & $2 \pm 0.016$ \\
\hline C & $47-70$ & $13 \pm 0.065$ & $14 \pm 0.112$ \\
\hline \multicolumn{4}{|c|}{ Umbrisols } \\
\hline $\mathrm{O}$ & $0-7$ & $14 \pm 0.07$ & $13 \pm 0.104$ \\
\hline AY & $7-30$ & $11 \pm 0.055$ & $49 \pm 0.392$ \\
\hline Gox & $30-60$ & $7 \pm 0.035$ & $13 \pm 0.104$ \\
\hline \multicolumn{4}{|c|}{ Podzols } \\
\hline AY & $0-15$ & $9 \pm 0.045$ & $20 \pm 0.16$ \\
\hline $\mathrm{BHF}$ & $15-28$ & $13 \pm 0.065$ & $19 \pm 0.152$ \\
\hline CRg & $28-60$ & $5 \pm 0.025$ & $22 \pm 0.176$ \\
\hline \multicolumn{4}{|c|}{ Crysols } \\
\hline $\mathrm{O}$ & $0-7$ & $18 \pm 0.09$ & not determined \\
\hline AY & $7-16$ & $14 \pm 0.07$ & $5 \pm 0.04$ \\
\hline CR & $16-27$ & $13 \pm 0.065$ & $34 \pm 0.272$ \\
\hline Cox & $27-35$ & $17 \pm 0.085$ & $21 \pm 0.168$ \\
\hline \multicolumn{4}{|c|}{ Histosols } \\
\hline $\mathrm{O}$ & $0-8$ & $11 \pm 0.055$ & not determined \\
\hline Teg & $8-20$ & $11 \pm 0.055$ & $16 \pm 0.128$ \\
\hline \multicolumn{4}{|c|}{ Gleysols } \\
\hline $\mathrm{O}$ & $0-7$ & $22 \pm 0.11$ & $54 \pm 0.432$ \\
\hline $\mathrm{AH}$ & $7-20$ & $12 \pm 0.06$ & $57 \pm 0.456$ \\
\hline G & $20-25$ & $16 \pm 0.08$ & $10 \pm 0.08$ \\
\hline
\end{tabular}

where, SOC - soil organic carbon $\left(\mathrm{kg} / \mathrm{m}^{2}\right) ; \rho$ - horizon density; Coc - Organic carbon content (\%); 0,1 - conversion factor; $\mathrm{H}-$ depth.

Table 3. The carbon stocks for all six studied soil groups in "dry combustion" and in Tyurin's methods. The values are in $\mathrm{kg} / \mathrm{m}^{-2} \pm \mathrm{SD}$

\begin{tabular}{|c|c|c|}
\hline \multirow[t]{2}{*}{ SoilGroups } & \multicolumn{2}{|c|}{$\begin{array}{l}\text { Estimate of organic carbon stock by } \\
\text { "dry combustion" }\left(\mathrm{CcO}_{2}\right) \text { and } \\
\text { Tyurin's methods (Cox), kg/m² }\end{array}$} \\
\hline & $\mathrm{CCO}_{2}$ & Cox \\
\hline Fluvisols & $17 \pm 0.008$ & $21 \pm 0.017$ \\
\hline Umbrisols & $6 \pm 0.003$ & $18 \pm 0.014$ \\
\hline Podzol & $6 \pm 0.003$ & $16 \pm 0.013$ \\
\hline Cryosols & $5 \pm 0.002$ & $12 \pm 0.01$ \\
\hline Histosols & $1 \pm 0.0005$ & $13 \pm 0.01$ \\
\hline Gleysols & $4 \pm 0.002$ & $16 \pm 0.013$ \\
\hline
\end{tabular}

Our results show that the degree of intramolecular oxidation and reduction of organic matter is a very extensive parameter of humus. Data obtained by Tyurin's method are inaccurate for monitoring values. Data of the conversion coefficients $(\mathrm{Kc})$ can form the basis of tables of conversion of organic carbon from values obtained us- 
ing Tyurin's method to estimate carbon values using "dry combustion" method (Abakumov and Popov, 2005).

A great many of studies are devoted to carbon stocks and organic carbon content in Arctic soils. The data we obtained now fully correlate to the data reported by others. Soils are characterized by increase to $34 \%$ or more of humus content from 14 to $45 \mathrm{~kg} / \mathrm{m}^{2}$ (Zubrzycki et al., 2013; Zubrzycki et al., 2014; Savich et al., 2015).

Arctic zone is under threat of soils degradation with the following remobilization of organic matter that was sealed under continuous permafrost to global carbon cycle due to global climate warming (Zubrzycki et al., 2013; Zubrzycki et al., 2014).

The question remains using Tyurin's method of carbon determination through correction rates. Tyurin's method compare to "dry combustion" method has several inaccuracies, which appear due to wet combustion of carbon through potassium dichromate. That is caused by oxidizer overconsumption during oxidation of halogens, Fe ions and molecules enriched with hydrogen. Also, a high content of partially decomposed organic residues can play a key role in determining organic carbon by these methods (Kogut et al., 1992; Kogut and Frid, 1993; Abakumov and Popov, 2005).

\section{Conclusions}

The conducted work has shown the evaluation of one of the main ecological features of soil of the Arctic zone deposition capacity of soil in relation to organic carbon. On the basis of the data on carbon stocks within all groups of soils located in the Lena River Delta, the stocks of total carbon were estimated. Soils, that located where flooding processes occurs, are characterized by the highest rate of organic matter content up to $20 \mathrm{~kg} / \mathrm{m}^{2}$ in Fluvisols, which in conditions of low biological activity tend to accumulate and seal. Soils, the formation of which occurs on the formed soil-forming rock located in the river delta, are characterized by low carbon content rate from 13 to $17 \mathrm{~kg} /$ $\mathrm{m}^{2}$. It can be related to internal processes occurring in the soil, organic carbon is buried in permafrost-affected soils.

We further presented comparison of data obtained using "dry combustion" and Tyurin's method of organic carbon determination. The difference of the values obtained by two methods differed more than $2-4$ times. Tyurin's method represents inaccuracy for $\mathrm{Cco}_{2}$ determination. Inaccuracy occurs when oxidizer gives extra force to oxidase halogens, $\mathrm{Fe}^{+2}$ and intramolecular hydrogen. The high content of undecomposed residues also strongly affects the results obtained by the Tyurin's method.

The total reserves of organic carbon in soils can vary substantially when using "dry combustion" method that can lead to overestimating of soil carbon stocks. That is one of the important points for carbon stocks determination for great areas.

\section{References}

Abakumov, E. V., Popov, A. I. 2005. Determination of the carbon and nitrogen contents and oxidizability of organic matter and the carbon of carbonates content in one soil sample. Eurasian soil science 2:165-172.

Betelev, N. P. 2006. Determination of carbon content and other research with use of dry burning. Bulletin of Moscow society of naturalists. Department geological 2:62-73.

Bezuglova, O.S., Gorbov, S. N., Karpushova, A. V., Tagiverdiev, S. S. 2014. The comparative characteristic of methodsfor determination of organic carbon in soils. Biological sciences 8:1576-1580.

Bolshiyanov, D. Y., Makarov, A.S., Schneider, V., Shtof, G. 2013. Origin and development of the Lena River Delta, St. Petersburg: AARI.

Cauwet, G., Sidorov, I. 1996. The biogeochemistry of Lena River: organic carbon and nutrients distribution. Marine Chemistry 53:211-227. doi: 10.1016/03044203(95)00090-9

Ejarque, E., Abakumov, E. 2016. Stability and biodegradability of organic matter from Arctic soils of Western Siberia: insights from ${ }^{13} \mathrm{C}-\mathrm{NMR}$ spectroscopy and elemental analysis. Solid Earth 7:153-165. doi: 10.5194/se-7-153-2016

Höfle, S., Rethemeyer, J., Mueller, C.W., and John, S. 2013. Organic matter composition and stabilization in a polygonal tundra soil of the Lena Delta. Biogeosciences 10:3145-3158. doi: 10.5194/bg-10-3145-2013

Knoblauch, C., Beer, C., Sosnin, A., Wagner, D., and Pfeiffer, E.-M. 2013. Predicting long-term carbon mineralization and trace gas production from thawing permafrost of Northeast Siberia. Global Change Biology 19:11601172. doi: $10.1111 / \mathrm{gcb} .12116$

Kogut, B. M. and Frid, A. S. 1993. Comparative evaluation of methods for determining the content of humus in soils. Pochvovedenie 9:119-123.

Kogut, B. M., Krasnova, N. M., Bol'shakov, V.A. 1992. Analytical support of soil carbon monitoring. Pochvovedenie 12:138-143.

Lara, R. J., Rachold, V., Kattner, G., Hubberten, H. W., Guggenbergen, G., Skoog, A., Thomas, D. N. 1998. Dissolved organic matter and nutrients in the Lena River, Siberian Arctic: Characteristics and distribution. Marine Chemistry 59:301-309. doi: 10.1016/S0304-4203(97)00076-5

Orlov, D. S. 1985. Soil Chemistry: A Textbook, Moscow: Moscow State University.

Savich, V.I., Scriabin, D. S., and Norovskeren, G. 2015. Influence of cryogenesis on the genesis and fertility of permafrost and permafrost-taiga soils. Izvestiya TSKhA 2:5-14.

Schneider, J., Grosse, G., and Wagner, D. 2009. Land cover classification of tundra environments in the Arctic Lena Delta based on Landsat 7 ETM+ data and its application for upscaling of methane emissions. Remote Sens. Environ. 113:380-391. doi: 10.1016/j.rse.2008.10.013

Schumacher, B. A. 2002. Methods for the Determination of Total Organic Carbon (TOC) In Soils and Sediments. Ecological Risk Assessment Support Center. Las Vegas.

WRB World Reference Base of Soil Resources (2014): World soil resources. Report No. 106, FAO, Rome.

Zubrzycki, S., Kutzbach, L., and Pfeiffer, E.-M. 2014. Permafrost-affected soils and their carbon pools with a focus on the Russian Arctic. Solid Earth 5:595-609. doi: 10.5194/se-5-595-2014

Zubrzycki, S., Kutzbach, L., Grosse, G., Desyatkin, A., and Pfeiffer, E.-M. 2013. Organic carbon and total nitrogen stocks in soils of the Lena River Delta. Biogeosciences 10:3507-3524. 